\title{
PENGARUH AIR LAUT TERHADAP PENGURANGAN KADAR SULFUR PADA BATUBARA SUB-BITUMINUS
}

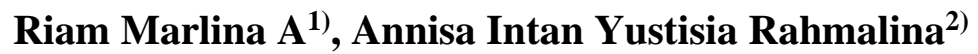 \\ 1,2 Program Studi Teknik Pertambangan (STTIND) Padang \\ email: riammarlina@sttind.ac.id
}

\begin{abstract}
Abstrak: Batubara di PT. Atoz Nusantara Mining mempunyai nilai kalori $5130 \mathrm{kcal} / \mathrm{kg}$, ash content 33,50 (\% adb) dan total sulfur 2,25 (\%adb), sehingga digolongkan pada batubara subbituminus dengan kadar sulfur yang tinggi. Perlu dilakukan penurunan kadar sulfur pada batubara. Salah satu usaha untuk menurunkan kadar sulfur tersebut adalah dengan pencucian batubara menggunakan metode flotasi. Pengurangan kadar sulfur pada batubara selain menghilangkan pencemar juga untuk menaikan nilai kalori sehingga dapat meningkatkan harga jual batubara. Tujuan penelitian ini adalah mengetahui tingkat kadar sulfur batubara sub-bituminus sesudah dilakukan pencucian dengan sistem flotasi menggunakan air laut. Pencucian batubara menggunakan metoda flotasi dengan campuran air laut dan minyak tanah pada ukuran batubara 40 mesh, 60 mesh, 100 mesh, 200 mesh dan 325 mesh. Menggunakan sel flotasi dengan volume air laut $1 \mathrm{~L}$, minyak tanah $40 \mathrm{ml}$ dan batubara 100 gr dengan waktu flotasi selama 7 menit. Setelah batubara dicuci, lalu dikeringkan selama 7 hari. Selanjutnya di uji laboratorium untuk mengetahui nilai kalori dan kadar sulfur hasil pencucian. Hasilnya sampel mengalami pengurangan kadar sulfur signifikan. Rata- rata pengurangan kadar sulfurnya sebesar $25,04 \%$. Pengurangan kadar sulfur tertinggi terjadi pada sampel ukuran 325 mesh sebesar 28,9\%. Sampel juga mengalami kenailkan nilai kalori, dengan rata-rata kenaikan nilai kalori 4,04\%.
\end{abstract}

Kata kunci: Flotasi, Batubara, Air Laut, Sulfur, Kalori

Abstract: Coal at PT. Atoz Nusantara Mining is generally classified as sub-bituminous coal with high sulfur content. It is necessary to reduce sulfur content in coal. One effort to reduce sulfur levels is by washing coal using the flotation method. The effort to reduce sulfur content in coal besides eliminating pollutants is also an effort to increase the calorific value so that it can increase the selling price of coal. Coal washing uses the flotation method with a mixture of sea water and kerosene on coal sizes of 40 mesh, 60 mesh, 100 mesh, 200 mesh and 325 mesh. Using flotation cells with 1 L volume of sea water, $40 \mathrm{ml}$ kerosene and $100 \mathrm{gr}$ coal with flotation time for 7 minutes. After the coal is washed, then dried for 7 days. Furthermore, in laboratory tests to determine the caloric value and sulfur content of the washing results. The result is that the sample experiences a significant reduction in sulfur content. The average reduction in sulfur content is $25.04 \%$. The highest reduction in sulfur content occurred in 325 mesh samples by $28.9 \%$. The sample also experienced a calorific value score, with an average calorific value increase of $4.04 \%$.

Keywords: Flotation, Coal, Sea Water, Sulfur Content, Calorie Value 


\section{PENDAHULUAN}

Batubara adalah salah satu bahan bakar fosil yang terbentuk dari endapan organik dimana unsur-unsur utamanya terdiri dari karbon, hidrogen dan oksigen. Batubara hasil penambangan mengandung bahan pengotor (impurities). Hal ini terjadi ketika proses coalification (pembatubaraan) ataupun pada proses penambangan. Ada dua jenis pengotor batubara yaitu Inherent impurities, merupakan pengotor bawaan yang terdapat dalam batubara dan Eksternal impurities, merupakan pengotor yang berasal dari luar yang berasal dari lapisan penutup.

Inherent Impurities dapat berupa gybsum $\left(\mathrm{CaSO}_{4} 2 \mathrm{H}_{2} \mathrm{O}\right)$, anhidrit $\left(\mathrm{CaSO}_{4}\right)$, pirit $\left(\mathrm{FeS}_{2}\right)$, silica $\left(\mathrm{SiO}_{2}\right)$. Sulfur dalam batubara terdapat dalam bentuk anorganik, dan organik. Pirit $\left(\mathrm{FeS}_{2}\right)$ merupakan sulfur anorganik selain markasit (FeS2) dan sulfat yang terdapat pada batubara. Sulfur merupakan elemen-elemen impurities (kotoran pengganggu), disamping kotoran lainya seperti tanah, batuan, mineral dan lain-lain. Usaha pengurangan kadar abu dan kadar sulfur pada batubara, selain menghilangkan unsur pencemar, juga merupakan usaha menaikkan nilai kalori batubara itu sehingga dapat memberikan nilai tambah yang mirip dengan batubara kualitas tinggi ( Nukman dan Poertadji, 2006). Unsur sulfur terdapat pada batubara dengan kadar bervariasi dari rendah (jauh di bawah 1\%) sampai lebih dari $4 \%$. Menurut (Kepmen) ESDM Nomor 1395 K/30/MEM/2018 Sulfur batubara dikatakan tinggi apabila besar dari $0,8 \%$ dan ash content maksimal yang di perbolehkan sebesar $26,30 \%$.

Sulfur pada batubara dapat dikurangi kadarnya dengan cara mencuci batubara tersebut, salah satu metoda yang dapat digunakan yaitu dengan menggunakan metoda flotasi (Nukman dan Basri, 2007). Metode flotasi sangat cocok diterapkan pada pencucian batubara kerena sifat batubara yang hidrofobik (benci air).

Dalam flotasi perlu sekali diperhatikan faktor-faktor yang menyangkut gaya berat yang berkaitan dengan density mineral, gaya apung gelembung-gelembung yang naik ke permukaan, diameter batubara, sifat hidrophobik partikel batubara yang berhubungan dengan sifat adhesi surfaktan, dan juga tegangan permukaan (Truscott, 1923; Taggart, 1954; Gennes, 2004). Flotasi buih pada batubara diawali dengan penggilingan dan penghalusan untuk mendapatkan permukaan butiran yang luas sehingga dimungkinkan terjadinya kontak maksimum antara gelombang udara dengan butiran batubara ( Sundari, 2010).

Menurut Klassen dan Mokrousov dalam O. Ozdemir (1930), para peneliti di bekas Uni Soviet menemukan bahwa mineral hidrofobik alami seperti batubara dapat mengapung dalam larutan elektrolit tanpa menggunakan kolektor dan frothers. Dan menurut Li dan Somasundaran dalam O.Ozdemir. Menunjukkan bahwa efisiensi flotasi tergantung pada tingkat perpaduan gelembung. Mereka kemudian menegaskan bahwa sementara flotasi batubara menurun pada konsentrasi garam rendah, flotasi meningkat pada garam yang lebih tinggi. Air laut merupakan sumber konsentrasi garam. Hal ini lah yang melatar belakangi penulis untuk melakukan penelitian pengurangan kadar sulfur batubara dengan menggunakan air laut.

Tujuan penelitian ini adalah mengetahui tingkat kadar sulfur batubara sub-bituminus sesudah dilakukan pencucian dengan sistem flotasi menggunakan air laut. 


\section{METODE PENELITIAN}

Penelitian dilakukan untuk mengurangi kadar sulfur yang tinggi pada PT. Atoz Nusantara Mining (PT. ANM), yang tergolong batubara sub-bituminus dengan nilai kalori $5130 \mathrm{kcal} / \mathrm{kg}$, ash content 33,50 (\% adb) dan total sulfur 2,25 (\%adb).

Batubara yang diambil dari tambang dihaluskan hingga mencapai ukuran 60, 80, 100, 200 dan 325 mesh. Proses flotasi mengunakan air laut pada masing-masing ukuran batubara. Menggunakan Sel Flotasi dengan komposisi bahan yaitu 1 liter air laut, $40 \mathrm{ml}$ minyak tanah dan 100 gram batubara tiap sampelnya dengan waktu flotasi selama 7 menit.

Prinsip kerja dari selflotasi adalah umpan yang telah di olah berupa pulp atau lumpur dimasukkan ke dalam tangki atau sel flotasi. Tangki dilengkapi dengan agiator atau pengaduk yang teritegrasi dengan pipa untuk menginjeksi udara, sehingga timbul gelembung udara di dalam pulp. Mineral yang bersifat hidrofobik akan menempel pada gelembung udara kemudian terangkat menuju permukaan menjadi buih (mineralised froth), sedangkan mineral hidrofilik tetap tinggal di dalam pulp.

\section{HASIL DAN PEMBAHASAN}

Hasil dan pembahasan dari penelitian pengaruh air laut terhadap pengurangan kadar sulfur pada batubara sub-bituminus di PT. Atoz Nusantara Mining adalah sebagai berikut:

Sulfur awal 2,24\% (Adb) setelah pencucian menjadi $1,80 \%$ (Adb) terjadi pengurangan kadar sulfur sebesar 19,64\% dan pada sampel ukuran 325 Mesh dari kadar sulfur awal 2,25\% (Adb) setelah pencucian menjadi $1,60 \%$ (Adb) terjadi pengurangan kadar sulfur sebesar $28,9 \%$. Dari 5 sampel batubara dengan ukuran yang berbeda tersebut sampel 325 Mesh mengalami penurunan yang tertinggi., seperti terlihat pada Gambar 1 dibawah ini:

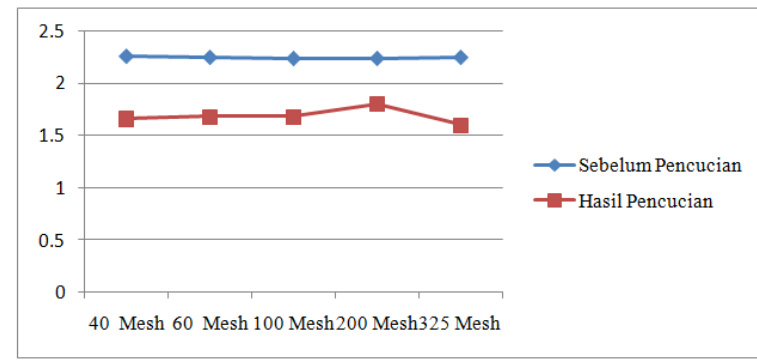

\section{Gambar 1 Nilai Kadar Sulfur Batubara Setelah Pencucian}

Dan terjadi kenaikan nilai kalori batubara sub-bituminus pada setiap ukuran sampel dengan persentase yang bervariasi. Tiap sampel yang peniliti lakukan mengalami kenaikan nilai kalori. Pada sampel ukuran 40 Mesh dari nilai kalori awal $5130 \mathrm{cal} / \mathrm{g}$ setelah pencucian menjadi $5320 \mathrm{cal} / \mathrm{g}$ terjadi kenaikan nilai kalori sebesar 3,7\%. Pada sampel ukuran 60 Mesh dari nilai kalori awal $5130 \mathrm{cal} / \mathrm{g}$ setelah pencucian menjadi $5410 \mathrm{cal} / \mathrm{g}$ terjadi kenaikan nilai kalori sebesar 5,4\%. Pada sampel ukuran 100 Mesh dari nilai kalori awal $5130 \mathrm{cal} / \mathrm{g}$ setelah pencucian menjadi $5410 \mathrm{cal} / \mathrm{g}$ kenaikan nilai kalori sebesar 5,4 $\%$. Pada sampel ukuran 200 Mesh dari nilai kalori awal $5130 \mathrm{cal} / \mathrm{g}$ setelah pencucian menjadi 5280 terjadikenaikan nilai kalori sebesar 2,9\% dan pada sampel ukuran 325 Mesh dari nilai kalori awal $5130 \mathrm{cal} / \mathrm{g}$ setelah pencucian menjadi $5550 \mathrm{cal} / \mathrm{g}$ terjadi kenaikan nilai kalori sebesar $8,19 \%$, seperti terlihat pada Gambar 2 dibawah ini:

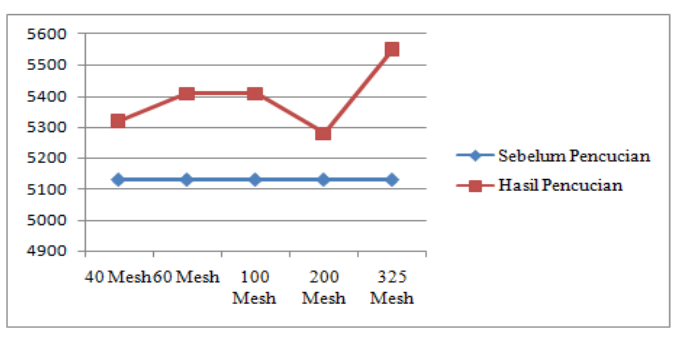

\section{Gambar 2 Nilai Kalori Batubara Setelah Pencucian}

Berdasarkan Gambar 1 dapat dilihat bahwa tiap-tiap sampel mengalami pengurangan kadar sulfur batubara, 
pengurangan cukup signifikan, kadar sulfur batubara yang banyak mengalami pengurangan yaitu pada sampel dengan ukuran 325 Mesh dari 2,25\% (Adb) menjadi $1,60 \%$ (Adb) dengan besar pengurangan kadar sulfur yaitu 28,9\%. Berdasarkan gambar 2 dapat dilihat bahwa tiap-tiap sampel mengalami kenaikkan nilai kalori batubara, namun tidak terlalu signifikan. Nilai kalori batubara tertinggi hasil pencucian yaitu pada sampel dengan ukuran 325 Mesh nilai kalori awal 5130 $\mathrm{cal} / \mathrm{g}$ setelah dicuci nilai kalorinya menjadi $5550 \mathrm{cal} / \mathrm{g}$ dengan besar persentase kenaikan sebesar $8,2 \%$.

Tabel 1 Nilai Kalori Dan Kadar Sulfur

\begin{tabular}{|c|c|c|c|c|c|c|}
\hline \multirow{2}{*}{$\begin{array}{l}\text { Ukuran } \\
\text { Sampel }\end{array}$} & \multicolumn{2}{|c|}{ Sebelum Pencucian } & \multicolumn{2}{|c|}{ Hasil Pencucian } & \multirow{2}{*}{$\begin{array}{c}\text { Pengurangan } \\
\text { Kadar } \\
\text { Sulfur }\end{array}$} & \multirow{2}{*}{$\begin{array}{c}\text { Kenaikan } \\
\text { Nilai } \\
\text { Kalori }\end{array}$} \\
\hline & $\begin{array}{c}\text { Kadar } \\
\text { Sulfur }\end{array}$ & $\begin{array}{c}\text { Nilai } \\
\text { Kalori }\end{array}$ & $\begin{array}{l}\text { Kadar } \\
\text { Sulfur }\end{array}$ & $\begin{array}{c}\text { Nilai } \\
\text { Kalori }\end{array}$ & & \\
\hline 40 mesh & $\begin{array}{l}2,26 \% \\
\text { (Adb) }\end{array}$ & $\begin{array}{l}5310 \\
\mathrm{cal} / \mathrm{g}\end{array}$ & $\begin{array}{l}1,66 \% \\
(\mathrm{Adb})\end{array}$ & $\begin{array}{l}5320 \\
\mathrm{cal} / \mathrm{g}\end{array}$ & $26,4 \%$ & $3,7 \%$ \\
\hline 60 mesh & $\begin{array}{l}2,25 \% \\
\text { (Adb) }\end{array}$ & $\begin{array}{l}5310 \\
\mathrm{cal} / \mathrm{g}\end{array}$ & $\begin{array}{l}1,68 \% \\
\text { (Adb) }\end{array}$ & $\begin{array}{l}5410 \\
\mathrm{cal} / \mathrm{g}\end{array}$ & $25,3 \%$ & $5,4 \%$ \\
\hline 100 mesh & $\begin{array}{l}2,24 \% \\
\text { (Adb) }\end{array}$ & $\begin{array}{l}5310 \\
\mathrm{cal} / \mathrm{g}\end{array}$ & $\begin{array}{l}1,68 \% \\
(\mathrm{Adb})\end{array}$ & $\begin{array}{l}5410 \\
\mathrm{cal} / \mathrm{g}\end{array}$ & $25 \%$ & $5,4 \%$ \\
\hline 200 mesh & $\begin{array}{l}2,24 \% \\
\text { (Adb) }\end{array}$ & $\begin{array}{l}5310 \\
\mathrm{cal} / \mathrm{g}\end{array}$ & $\begin{array}{l}1,80 \% \\
(\mathrm{Adb})\end{array}$ & $\begin{array}{l}5280 \\
\mathrm{cal} / \mathrm{g}\end{array}$ & $19,6 \%$ & $2,9 \%$ \\
\hline 325 mesh & $\begin{array}{l}2,25 \% \\
\text { (Adb) }\end{array}$ & $\begin{array}{l}5310 \\
\mathrm{cal} / \mathrm{g}\end{array}$ & $\begin{array}{l}1,60 \% \\
(\mathrm{Adb})\end{array}$ & $\begin{array}{l}5550 \\
\mathrm{cal} / \mathrm{g}\end{array}$ & $28,9 \%$ & $8,2 \%$ \\
\hline \multicolumn{5}{|c|}{ Rata-rata } & $25,04 \%$ & $4,04 \%$ \\
\hline
\end{tabular}

\section{KESIMPULAN}

Dari penelitian yang telah dilakukan dapat disimpulkan Pencucian batubara dengan air laut. Pada tiap sampel yang peniliti lakukan mengalami pengurangan kadar sulfur yang cukup signifikan. Dengan rata-rata pengurangan kadar sulfur sebesar $25,04 \%$. Pengurangan kadar sulfur tertinggi terjadi pada sampel ukuran 325 Mesh sebesar $28,9 \%$. Dan pengurangan kadar sulfur terendah terjadi pada sampel ukuran 200 Mesh sebesar 19,6\%.

\section{DAFTAR PUSTAKA}

Aladin, A. 2009. "Penentuan Rasio Optimum CPO, Batubara Dalam Desulfurisasi dan Deashing Secara Flotasi Sistem Kontinue". Universitas Muslim Indonesia: Makasar.
Anggayana, K. 2002."Ganesa Batubara". Departemen Teknik Pertambangan: FIKTM Institut Teknologi Bandung

Arif, I. 2014, Batubara Indonesia, Bandung: PT Gramedia Pustaka Utama.

Casagrande D J. 1987."Sulphur In Peat And Coal In: Scoft AC (Editor), Coal And Bearing Strata: Recent Advences". Geology Society Special Publication Vol 103. PP, 87-105.

Cook A. C. 1982." The Origin And Petrology Of Organik Matter In Coal Oil Shales And Petroleum SourceRock". Geology Departement Of Wolonggong University: Australia.

Damman W. H. Antoni, M. French. 1987."The Ecology Of Peat Bogs Of Glaciated Northeastern United States". U.S Department Of Interior: Washington, DC

Danang jaya, Dkk. 2016."Pemanfaatan CPO (Crude palm oil)) Untuk Desulfurisasi Pada Batubara Mengunakan Metode Flotasi". UPN (VETERAN): Yogyakarta.

Danang pratama. 2018." Pencucian Batubara Menggunakan Metoda Flotasi Untuk Menurunkan Kadar Abu Dan Kadar Sulfur Batubara Di Pt.Atoz Nusantara Mining".STTIND Padang: Padang.

Diesel C.F.K. 1992."Coal Bearing Depositional System Springer". Verlag: Germain

Heri Heryanto, Dkk.2014."Pengaruh Minyak Jelantah Pada Proses UBC Untuk Meningkatkan Kalori Batubara Baya". Universitas Sultan Ageng Tirtayasa: Banten.

Heryadi Herta. 2018."Teknologi Mineral Dan Batubara". Puslitbang Teknologi Mineral. 
Rita Sundari, Dkk. 2010."Aplikasi Metode Flotasi Buih Untuk Pencucian Batubara Peringkat Rendah". Teknik Pertambangan Universitas Trisakti: Jakarta.

Stach, 1982."Coal Petrology". Grebuder Borntrager: Germain.

Suits, Artur. 2000."Sulphur Diagenesis And Partitioning In Holocene Peru Shelf And Upper Slope Sediments “. Chemical Geology: Elsevier.

Wisher W. H. 2000.”Organic Sulphur In The Hard Coal Of The Statigraphic Layers Of The Upper Silesian Coal Basin". Chemical: Elsevier. 